\title{
Kennedy attacks Carter plan to cut biomedical research
}

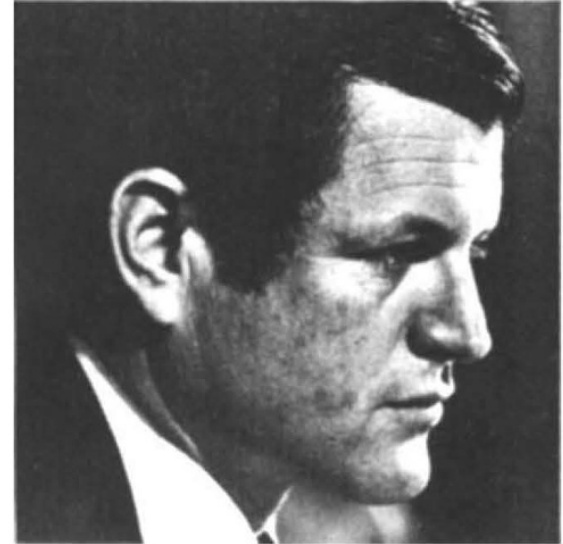

SENATOR Edward Kennedy (above) last week criticised as "surprising and disappointing" President Carter's budget recommendation that funds for biomedical research should be kept constant between 1979 and 1980. Allowing for inflation, this would mean a $10 \%$ cut on research spending.

The senator's remarks were made in an address to a group of medical research societies, including the American Federation for Clinical Research and the American Society for Clinical Investigation. His comments were welcomed by the 2,000 scientists present, as was his promise to take steps to reduce the amount of paperwork research workers are now required to complete. However, other suggestions included in a bill which Senator Kennedy has introduced into the Senate, such as a proposal to establish a President's council to prepare five-year plans for medical research, and the experimental inclusion of lay-people on some peer review committees, are being less warmly greeted by the medical community.

In his speech last week, Senator Kennedy, who is chairman of the $\mathrm{S}$ - nate sub-committee on health and science, said that the Administration's budget proposal to reduce spending on biomedical research next year-which Administration officials defend by pointing to the $25 \%$ increase in the current year-was both short-sighted and regrettable. "In 1967, the United States invested $4.9 \%$ of its health dollars in health science research. Today that figure stands at $3.4 \%$, and if the current Administration policy stands, that percentage will plummet further still," he said. Keeping up with inflation was the minimum that should be done to fund health science programmes.

But money alone was insufficient; visits to research centres around the country had convinced him that:

- It was time for Congress to commit itself "openly and squarely" to the support of investigator-initiated research in both the fundamental and the clinical sciences.

- Health science research workers were "drowning in paperwork and reporting requirements". Some scientists were spending as much as a quarter of their time filling out forms and doing mundane administrative chores.

- The Federal Government should restore some continuity and predictability to its federal health research budget, avoiding the recent series of confusing swings in research priorities at the federal level which were "unfair to scientists who have dedicated themselves in good faith to the directions mandated by the Federal Government."

Referring to the Health Science Promotion Act which he has recently introduced with Senator Javits to tackle some of these problems, Senator Kennedy asked the scientists for their help in making this "the kind of wise and constructive legislation which can help prepare our health science institutions for challenges of the 1980s". Some of the provisions in the proposed act, such as the legal status that it would provide to the National Institutes of Health (a status currently enjoyed only by its constituent institutes) have been generally welcomed by the medical research community, who recognise many of the symptoms that the senator described.

Other suggestions, however, have generated considerable controversy. These include the appointment by the President of an independent council to prepare and up-date a five-year forward look for health sciences, the involvement of scientists from other disciplines (such as physics or statistics) on NIH review panels; and to place, as an experiment, lay people on a sample number of peer review panels. Also controversial is a proposal that the mandates of the various institutes within the NIH should be renewed by Congress every few years, the first period for renewal coming up in 1983 . "To me that is antithetical to any longrange planning mechanism", one NIH staff member said.

There is also criticism of Senator Kennedy's suggestion that the director of NIH should have to ensure that at least $45 \%$ of NIH's biomedical research funds go to support investigatorinitiated research. At present, about $43 \%$ of funds are distributed this way. but NIH officials point out that things are never the same from one year to the next.

\section{Library report calls for a national periodicals centre}

THE setting up of a 'national periodicals centre' to compensate for the increasing number and price of academic journals-particularly in scientific and technical subjects-has been recommended by the National Enquiry on Scholarly Communication. In a three-year, $\$ 600,000$ study of research libraries published in New York last week, the national enquiry says that further growth in the number of scholarly journals should be discouraged, and concludes that major research libraries cannot expect major budget increases over the next decade.

The report says that if this conclusion is valid, "research libraries can no longer function as autonomous entities". And given the growing resistance to interlibrary loan, it recommends a national periodicals centre to provide libraries with a reliable source of copies of articles from journals too seldom used to warrant library subscription.

"The creation of a national periodicals center will lead to a changing environment for journal publishers, particularly in the science and technical disciplines," the report says. On the one hand, librarians would have a new option to consider: on the other, "the capacity created in the periodicals centre should increase the market for alternative forms of publications" such as storage on microform.

Among the reasons for such a centre having a greater effect on scientific disciplines are, the report says, that: - Subscription rates for scientific journals are far higher than they are for the humanities, so library savings from cancellations will be greater - There is often a premium on speed of publication and access in scientific fields, and the periodicals centre and improved bibliographic service will increase the attraction of using new forms of publication

- The market for scientific and technical materials is much broader than for the humanities, since many commercial firms follow the scientific literature.

The report admits that some scholars and journal editors have expressed fears about the impact of a national periodicals centre. It adds, however, that "there is simply no substitute for browsing through the current journals as a stimulus to thought and further research, and librarians are as aware of that as are faculty members."

Scholarly Communication is available from Johns Hopkins University Press, Baltimore 21218, US, price $\$ 3.95$. 